
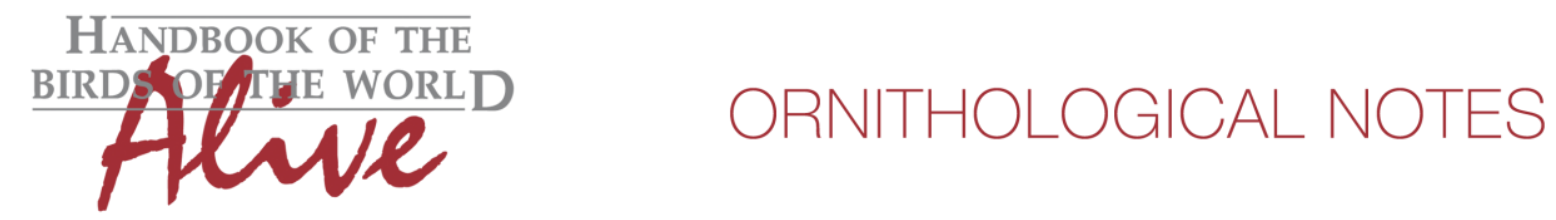

\title{
Notes on the vocalizations of Pearly-vented Tody-tyrant (Hemitriccus margaritaceiventer)
}

\author{
Peter Boesman
}

In the following we briefly analyze and compare voice of the different races of Pearly-vented Tody-tyrant (Hemitriccus margaritaceiventer). We also try to quantify the extent of any vocal differences using the criteria proposed by Tobias et al. (2010), as a support for taxonomic review. We have made use of sound recordings available on-line from Xeno Canto (XC) and Macaulay Library (ML).

Song of all races is a short rising series of sharp staccato notes followed by a trill descending in pitch, "tick-tick-tr' $r^{\prime} r^{\prime} r^{\prime} r^{\prime} r^{\prime} r^{\prime} r$ ". In some races full song is a gradual build-up of incomplete phrases till the full song phrase is given (and sometimes this sequence never gets to a full song with trill). There are many variant call series which may have a different function, e.g. phrases where the trill is replaced by an accelerating series of staccato notes etc.

We compare here exclusively a single 'full song phrase' among races (Fig. 1).

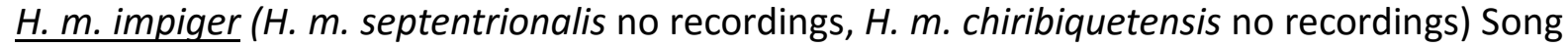
build-up rarely reaches the full song with a descending trill, but there are at least a few examples $(n=3)$

intro notes

$\begin{array}{lll} & \text { max. length } & 0.04-0.055 \mathrm{~s} \\ \text { min. av. freq. } & 2070-2700 \mathrm{~Hz} \\ \text { trill } & 3100-3600 \mathrm{~Hz} \\ & \\ & \text { length } & 0.35-0.40 \mathrm{~s} \\ \text { max. av. freq. } & 3400-3500 \mathrm{~Hz} \\ \text { min. av. freq. } & 2200-2300 \mathrm{~Hz} \\ \text { \# of notes } & 20-23 \\ \text { pace } & 0.017-0.0174\end{array}$

$\underline{H}$. m. auyantepui (H. m. duidae no recordings, H. m. breweri no recordings) $(n=5)$ intro notes

$\begin{array}{lll} & \text { max. length } & 0.04-0.07 \mathrm{~s} \\ & \text { min. av. freq. } & 2200-3100 \mathrm{~Hz} \\ \text { max. av. freq. } & 3200-3600 \mathrm{~Hz} \\ & \\ & \text { length } & 0.29-0.50 \mathrm{~s} \\ \text { max. av. freq. } & 3300-3600 \mathrm{~Hz} \\ \text { min. av. freq. } & 2700-3200 \mathrm{~Hz} \\ \text { \# of notes } & 11-20 \\ \text { pace } & 0.0235-0.0255\end{array}$




\section{HANDBOOK OF THE BIRDSPFGE WORLD}

\section{ORNITHOLOGICAL NOTES}

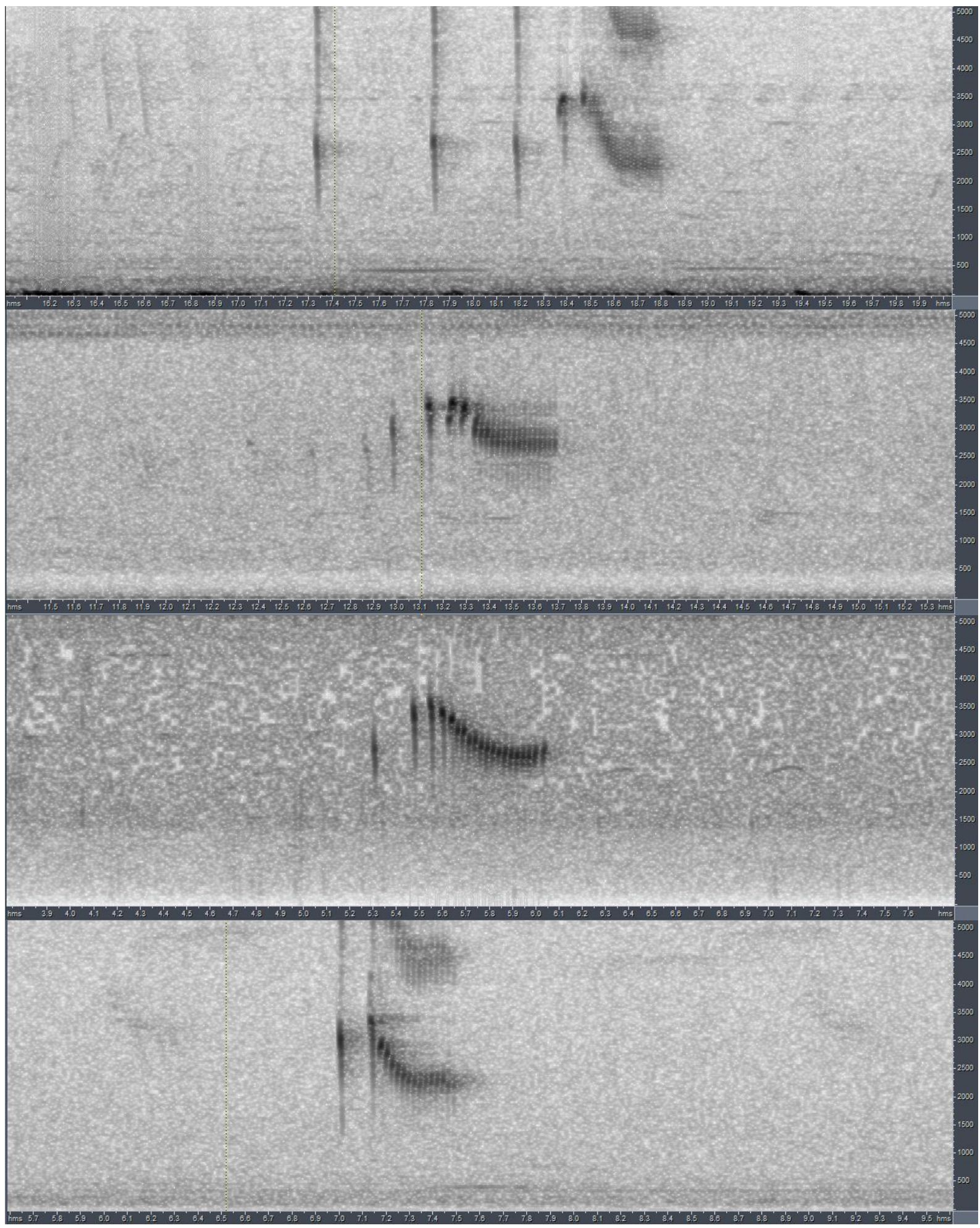

Figure 1: top to bottom: selected examples of full song for races impiger, auyantepui, rufipes and nominate. 

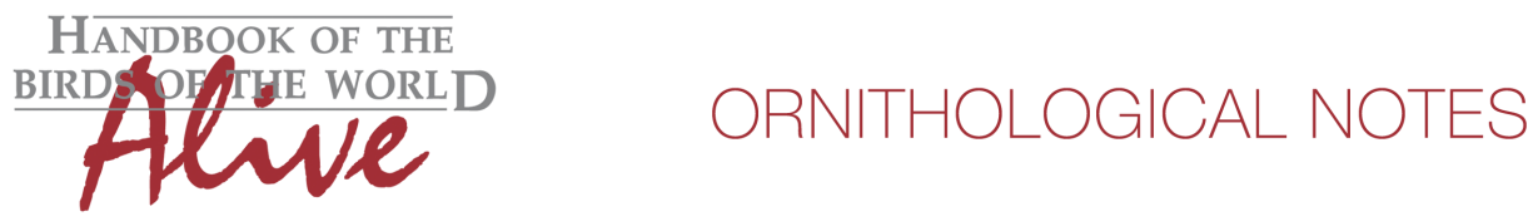

$\underline{H}$. $m$. rufipes Song build-up rarely reaches the full song with a descending trill, but there is at least one example $(n=2)$.

intro notes

$\begin{array}{lll} & \text { max. length } & 0.045 \mathrm{~s} \\ \text { min. av. freq. } & 2600 \mathrm{~Hz} \\ \text { max. av. freq. } & 3500 \mathrm{~Hz} \\ \text { trill } \quad & \\ & \text { length } & 0.5 \mathrm{~s} \\ \text { max. av. freq. } & 3400 \mathrm{~Hz} \\ \text { min. av. freq. } & 2600 \mathrm{~Hz} \\ \text { \# of notes } & 18 \\ \text { pace } & 0.27\end{array}$

H. m. wuchereri, H. m. margaritaceiventer $(n=10)$

intro notes

$\begin{array}{lll} & & \\ & \text { max. length } & 0.04-0.055 \mathrm{~s} \\ \text { min. av. freq. } & 1960-2700 \mathrm{~Hz} \\ \text { max. av. freq. } & 3300-4200 \mathrm{~Hz} \\ \text { trill } & \\ & \text { length } & 0.18-0.39 \mathrm{~s} \\ \text { max. av. freq. } & 3100-4100 \mathrm{~Hz} \\ \text { min. av. freq. } & 2200-3100 \mathrm{~Hz} \\ \text { \# of notes } & 8-18 \\ \text { pace } & 0.02-0.028\end{array}$

From the above measurements, it would seem that when comparing the homologous vocalization 'full song', there are hardly obvious differences among the 4 groups.

The only apparent difference is that the (rarely heard) trill of impiger has slightly more notes and a faster pace. This is however based on just a few examples. If these are representative, then vocal score vs all other races would be: higher number of notes (score 1-2) and faster pace (score 1-2), but we need more recordings to be confident about this vocal difference. All other races seemingly have no obvious differences in full song. Further detailed analysis may nevertheless discover some subtle differences in e.g. note shape, but this will not lead to a considerable vocal score according to Tobias criteria.

This note was finalized on 1st July 2015, using sound recordings available on-line at that moment. We would like to thank in particular the many sound recordists who placed their recordings for this species on XC and ML.

\section{References}

Tobias, J.A., Seddon, N., Spottiswoode, C.N., Pilgrim, J.D., Fishpool, L.D.C. \& Collar, N.J. (2010). Quantitative criteria for species delimitation. Ibis 152(4): 724-746. 


\section{Recommended citation}

Boesman, P. (2016). Notes on the vocalizations of Pearly-vented Tody-tyrant (Hemitriccus margaritaceiventer). HBW Alive Ornithological Note 125. In: Handbook of the Birds of the World Alive. Lynx Edicions, Barcelona. (retrieved from http://www.hbw.com/node/932048 on 5 August 2016). 